\title{
エポキシ樹脂塗装系の耐塩水性に及ぼす ジンクリッチペイントの効果*
}

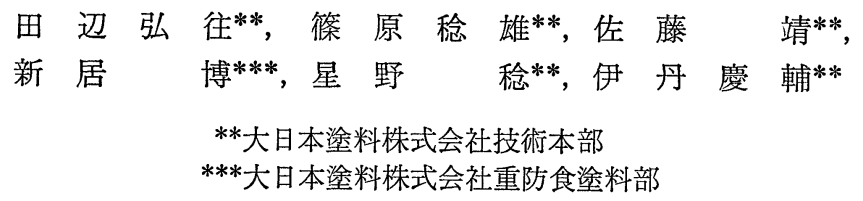

\author{
Effect of Zinc Rich Paints on the Durability of Epoxy Top Coats \\ in Sodium Chloride Solution*
Hiroyuki Tanabe**, Toshio Shinohara**, Yasushi Sato**, Hiroshi Nii***, Minoru Hoshino** and Keisuke Itami**
**Research and Development Department, Dai Nippon Toryo Co., Ltd. ***Anti-Corrosion Department, Dai Nippon Toryo Co., Ltd.

\begin{abstract}
Effect of inorganic zinc rich paints on the durability of epoxy top coat was investigated in $3 \mathrm{wt} \%$ sodium chloride solution. It was found that paint failure of epoxy top coat such as blisters was predicted by polarization resistance measurement, impedance measurement, electrode potential measurement of the coated mild steel. The coated mild steel which had no failure for 400 days hold high polarization resistance over the same period. The coated steel also kept a initial value of high impedance. The same sample showed only a slight shift of electrode potential toward the less noble direction. Epoxy top coat over zinc rich paints had no failure after 400 day service and the system was superior to the epoxy top coat which was directly applied to the blasted steel.

As a conclusion, the coating system that epoxy top coat was applied to zinc rich paint-coated steel showed the most excellent durability in $3 \mathrm{wt} \%$ sodium chloride solution, evaluating from electrochemical measurements and the result coincided with the observation of the test panels.
\end{abstract}

\section{1. 緒言}

最近，防食塗装への認識が深まる中で，その使用環境 は一層厳しいものになっている。鉄に対して顕著な防食 効果を有することから，ジンクリッチペイントは鋼構造 物への防食を目的として積極的に使用されるに至ってい る。またこのジンクリッチペイントに上塗りを塗装する ことも普通のことになっている。

これまでジンクリッチペイントの防食性についての報 告は多数ある。そして，これを電気化学的に取り披う場 合は，電位測定によることが多い1)。ジンクリッチペイ ントの防食電流密度を測定した報告もある2)。またジン

* 塗膜下腐食の研究（第 4 報） (Studies on Underfilm Corrosion (Part 4)) 第60 回金属表面技術学 術講演大会.

**,*** 厂230 横浜市鶴見区大東町 12-1 (12-1, Daito-cho, Tsurumi-ku, Yokohama, 230 Japan)
クリッチペイントに上塗り塗装を流どこした場合の報告 も多くみられるが, 電気化学的にこの塗装系の劣化過程 を考察したものはほとんどない。

筆者らは通常の高抵抗塗膜を塗装した鋼板の塗膜下腐 食, 和よびジンクリッチペイント塗装鋼板の防食性につ いて，電気化学的方法による検討結果を報告した ${ }^{5), 6) 。 ~}$ 本報告ではエポキシ樹脂系塗料の耐塩水性について, ジンクリッチペイントを塗装しない場合と比較し，その 防食性の評価法の検討を行った。

\section{2. 実験方法}

\section{1 試験片の調製}

被塗装試験片には軟 鋼板（JIS G $314150 \times 150 \times 1.6$ $\mathrm{mm})$ をサンドブラスト処理したものを使用した。この 鋼板に, アルキルシリケート系無機ジンクリッチペイン トをスプレー塗装し， $110 \mu \mathrm{m}$ の膜厚を得た。このジン 
クリッチ塗装鋼板, およびサンドブラスト鋼板に, 種類 の異なる 3 種のポリアマイド硬化型エポキシ樹脂塗料を $150 \mu \mathrm{m}$ ないし $200 \mu \mathrm{m}$ の膜厚でスプレー塗装した。こ れらの塗装系を対象にして, エポキシ樹脂塗膜下のジン クリッチペイントの防食性を検討した。表-1 にこれら の塗装系を示した。

Table 1. Coating system.

\begin{tabular}{cccc}
\hline System & Zinc rich paints & Epoxy coatings \\
\hline 1 & $\begin{array}{c}\text { Ethylsilicate } \\
110 \mu \mathrm{m}\end{array}$ & A & $310 \mu \mathrm{m}$ \\
2 & - & A $300 \mu \mathrm{m}$ \\
3 & Ethylsilicate & B $250 \mu \mathrm{m}$ \\
4 & - & B $310 \mu \mathrm{m}$ \\
5 & Ethylsilicate & C $300 \mu \mathrm{m}$ \\
6 & & C & $300 \mu \mathrm{m}$ \\
\hline
\end{tabular}

\section{2 測定方法}

試験液 (3 wt \% 塩化ナトリウム水溶液) 中に塗装試験 片を室温にて浸漬した。2.1で調製した塗装鋼板の自然 電極電位（飽和甘录電極照合），交流インピーダンスの 周波数依存性, 前報らで報告した塗膜下の腐食速度と密 接な関係にある分極抵抗を測定し，各種叙装系の防食性 の評価を試みた。測定には, 前報5)と同一セルを使用し, その測定対象面積は $12.6 \mathrm{~cm}^{2}$ とした。これと並行して, 浸漬過程における塗膜欠陥の発生状況の肉眼観察之, 同 時に湿潤付着力測定を行って, 塗膜下の状態を考察し た。

\section{3. 結果と考察}

\section{1 分極抵抗}

塗膜下の腐食速度を予測する分極抵抗を測定する方法 は，有機質塗膜塗装鋼板，ジンクリッチペイント塗装鋼

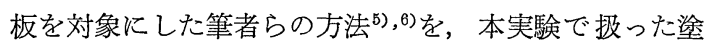
装系に適用した。

図 1 亿サンドブラスト処理鋼板に直接エポキシ樹脂塗 料落塗装した場合（塗装系（2）拉よび (6)）の，分極抵 抗の経時变化を示した。図の曲線は共に 2 種類のポリア マイド硬化型のエポキシ樹脂塗膜の例であるが，これら の分極抵抗の経時変化に大きな差がある。塗装系 (6) で は，その分極抵抗に汪とんど経時変化がみられず，その 值も $10^{8} \Omega \mathrm{cm}^{2}$ 以上を 400 日以上にわたり保持し, 極め て良好な塗膜であった。一方別の種類のエポキシ樹脂叙 膜の塗装系 (2)では分極抵抗の経時的減少は著しかった。 その初期に $10^{8} \Omega \mathrm{cm}^{2}$ 以上示していたのが，150日間を 経過すると著しい減少を示した。また 150 日以後 400 日 に至るまで減少の速度は緩やかになったが，やはり減少

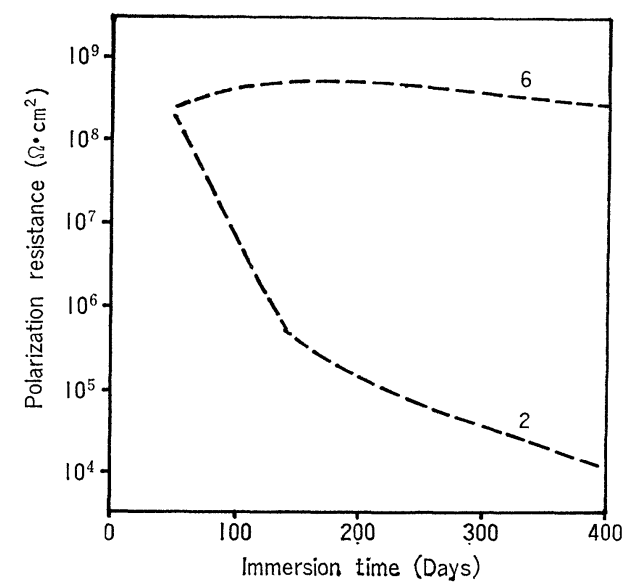

Fig. 1. The change of polarization with immersion time of epoxy coated steel without zinc rich paints. $3 \mathrm{wt} \%$ sodium chloride solution.

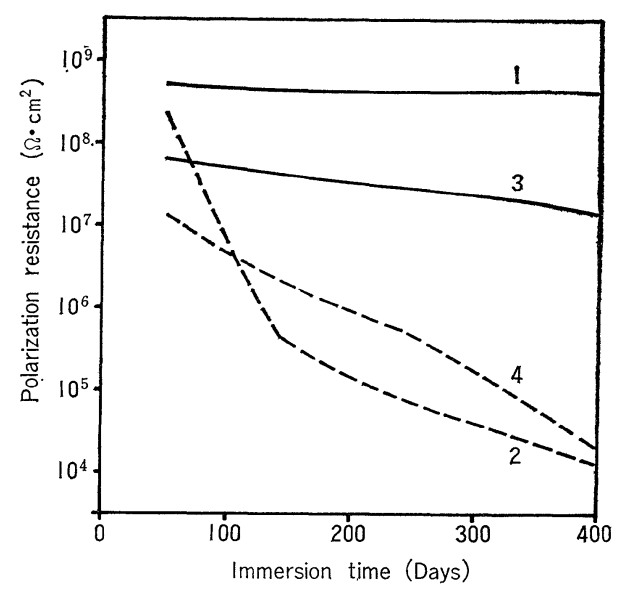

Fig. 2. The change of polarization resistance of epoxy coated steel with immersion time.

1 and 3: with zinc rich paints.

2 and 4 : without zinc rich paints.

$3 \mathrm{wt} \%$ sodium chloride solution.

を続け $10^{4} \Omega \mathrm{cm}^{2}$ まで低下した。以上のように，エポキ シ塗膜の種類によって分極抵抗の経時変化に著しい差が ある。本報告では多数の実験例のうち 400 日の期間以内 に比較検討が容易であったエポキシ樹脂塗膜塗装系(1), （2）および (3)，(4) を選び，以後の検討に供した。

図 2 は, エポキシ樹脂塗膜の下塗りにジンクリッチペ イント塗膜を塗装した場合と, エポキシ樹脂塗膜を直接 サンドブラスト処理鋼板に塗装した場合の, 塗膜下金属 表面の分極抵抗の経時変化を測定した結果である。図中 の塗装系 (1) と (2), および塗装系 (3) と (4) はとれぞれ 同種のエポキシ樹脂塗膜の場合である。また (1) および (3) はジンクリッチペイントをエポキシ樹脂塗膜の下塗 りに塗装した場合である。サンドブラスト処理鋼板に直 
接エポキシ樹脂塗膜を塗装した系 (2) では，初期の50 日経過後では，その分極抵抗は $3 \times 10^{8} \Omega \mathrm{cm}^{2}$ とかなり 大きいが，その後 140 日に至るまで著しい低下を見せ， さらら 400 日に至るまで滅少を続けた。これに対しジン クリッチペイントを下塑りとした塗装系 (1)では, 浸漬 の初期には $7 \times 10^{8} \Omega \mathrm{cm}^{2}$ の分極抵抗定示し，その後も 浸清日数 400 日洷るまで汪とえど低下しなかった。

別の例を (3)，(4) に示した。この場合にもサンドブ ラスト処理鋼板に直接エポキシ樹脂塗膜を施したものは 分極抵抗の著しい経時的低下がみられた。ジンクリッチ ペイント下塗り塗装系では極めて僅かな分極抵抗の低下 が認められたにすぎなかった。

また，浸漬の比較的初期からアルキルシリケート系ジ ンクリッチペイントを下塗りとするエポキシ樹脂塗膜塗 装鋼板の塗装系 (1)（または（3））の分極抵抗は，溆装 系（2）(または（4）のそれに比較し，大きい值を得た ダ，ここで留意したいのは，現場で塗装実例ではジン クリッヂペイント下塗りエポキシ樹脂塗膜にフクレが発 生した場合も山り，前報(で報告したようにジンクリッ チペイントの種類による分極抵抗值も幅広く, $10^{2} \Omega \mathrm{cm}^{2}$ から $10^{4} \Omega \mathrm{cm}^{2}$ の範围湟存在することから, 分極抵抗值 そのるのから必ずしも塗膜の耐久性を現段階では予測す ることはできない。ただ言党ることは，上塗りを含めた 整装系の分極抵抗の経時変化が大きいものは，フクレ久 陥が早期に発生する傾向に每ることである。

さらに長期間の浸漬で，分極抵抗の低下は塗装系 (2) （または(4)）では著しかった。この理由は塗膜下鋼板の 腐食の焦行, 牤よびそれに伴ら腐食生成物質が塗膜の久 宿発生に関係があるものと推定される。本報告で示した 例の法かに, 異種のエポキシ樹脂叙料 13 種類について, 並行して行った結果, 数例にフクレの発生を確認した。 フタレが発生した例で，その時の分極抵抗を測定すると $10^{6} \Omega \mathrm{cm}^{2}$ 以下であり，いずれもブラスト処理鋼板に直 接エポキシ樹脂塗料を塗装した系であった。図 3 はこれ らの外観観察写真である。写真 (b) は左側がジンクリッ チペイント下塗りのエポキシ樹脂塗料塗装系 (5), 右側 が直接サンドブラスト処理鋼板にエポキシ樹脂塗膜を叙

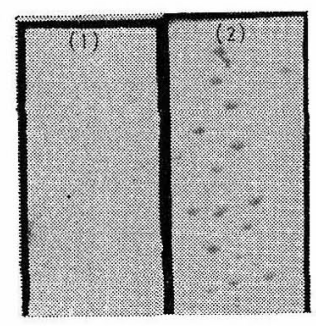

(a)

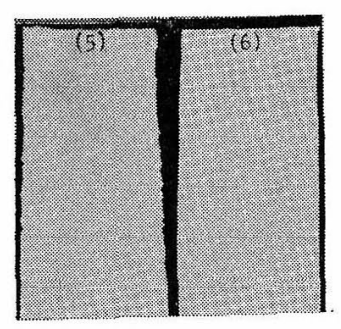

(b)
Fig. 3. Photos of 400 day immersed panels.

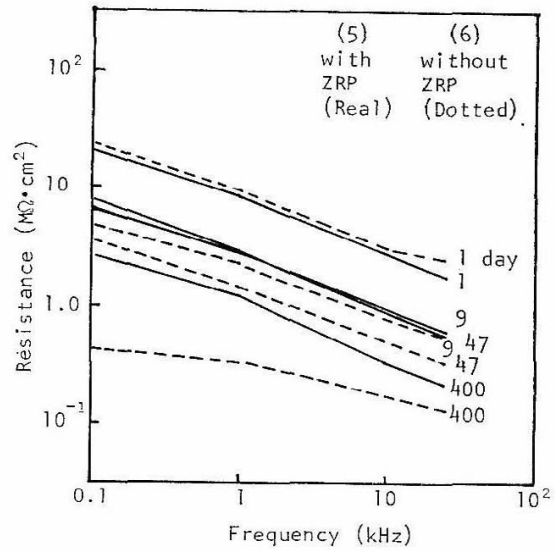

Fig. 4. The change of impedance with immersion time of epoxy coated steel with and without zinc rich paints.

装した系 (6) である。塩水浸漬 400 日後, 双方ともフタ レの発生はみられない。しかし塗装系 (6) の方が幾分交 流抵抗值は大で㚾った。写真 (a) はフクレの発生した場 合の例である。右側が塗装系 (2) の場合で，フクレの発 生がある。塗装系 (1) では全くフクレの発生がなが た。(a) の傾向は他にる数例みられた。

図 4 亿塗装系 (5)，（6）の交流抵抗の周波数依存性を 示した。写真 (b) に文ら机る, 浸漬 400 日後に外観観察 によるフクレの発生が㸾められなかったものである。交 流抵抗測定では，抵抗値の低下之共に低周波数域での勾

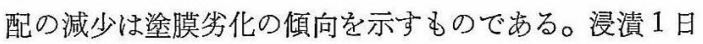
では，䤠装系 (6) のうが僅かながら高抵抗值を示した。 浸漬 9 日では，添汸同等かやや逆転の傾向がみられ，浸 漬 47 日後には逆転傾向が顕著になり, 璱装系 (5) がよ り大きい交流抵抗值を示した。浸漬 400 日後ではさらに その傾向が顕著になった。サンドブラスト処理鋼板に塗 装した系では乞の周波数依存性が小さく，また外観で〉 クレが認められなくても，交流抵抗值に大きな差を生じ た。写真 (a) 飞相当する塗装系の交流抵抗值の経時変化 を図 5 に示す。(b) の場合と同様に，ジンクリッチペイ ント下塗りの塗装系 (1) の場合, 浸漬 1 日ではかなり高 い抵抗值学示し，サンドブラスト処理鍴板の場合とほぼ 同等だが，その後の挙動が罢なり，浸漬 9 日から 250 日 に至るまでは洼涪同程度の交流抵抗值を与克，400 日比 至ってとの減少穵みせた。サンドブラスト銅板への直接 塗装系比比較して，減少の程度は僅かなるのであった。 塗装系 (2) では浸漬 50 日までは, 塗装系 (1) の分極抵 抗值と大差ないが，浸漬 180 日になって著しい抵抗値の 低下がみられ，その傾きも減少した。交流抵抗值の低下 は浸漬 250 日，400日と経過するにつれて著しかった。 そして浸漬 400 日の時点ではその抵抗值は $10^{5} \Omega \mathrm{cm}^{2}$ を 


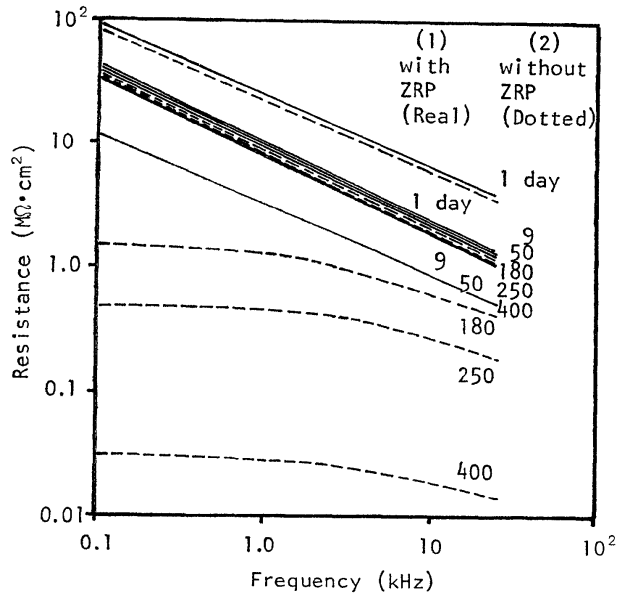

Fig. 5. The change of impedance with immersion time of epoxy coated steel with and without zinc rich paints.

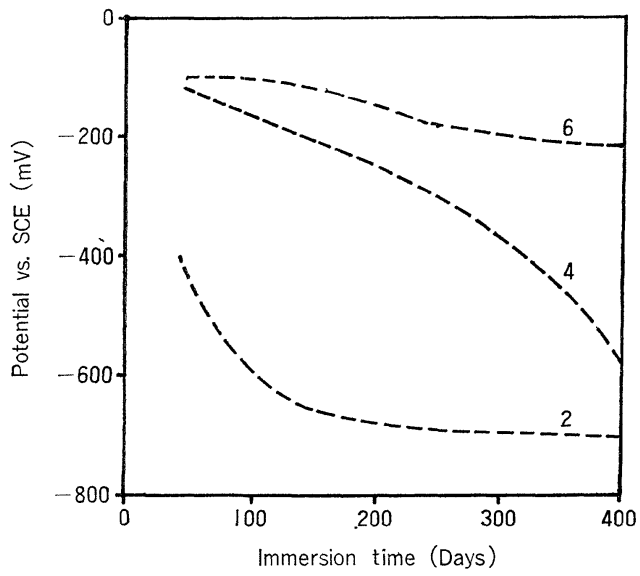

Fig. 6. The potential change with immersion time of epoxy coated steel without zinc rich paint. $3 \mathrm{wt} \%$ sodium chloride solution.

下まわり外観もフクレの発生がかなり認められた。交流 抵抗の経時変化は，下地の種類により差が生じることは すでに示したが，これと並行して電位の経時変化を測定 した。塗装鋼板の電位はしばしば，塗膜の健全度を定性 的に把握するのに有効である。一般に貴の電位を与兄る 塗装鋼板は健全塗膜を有するものと推定される。またエ ポキシ樹脂塗膜の下にジンクリッチペイントを塗装した 系では，その与える電位の意味は少し複雑である。ジン クリッチペイントが正常に機能しておれれば，それ自体の 電位になる。すなわち上塗りのない, ジンクリッチペイ ント単独系ではその電位は - $1000 \mathrm{mV}$ vs. S.C.E. 程度 の電位を有する。したがって本報告にあるようなエポキ シ樹脂塗料上塗り塗装系では, 単に下地あるいは下塗り の電位が直接影響するものと考えられるが，実験結果は
異なっていた。図 6 はサンドブラスト処理鋼板に 3 種の エポキシ樹脂塗料を塗装した場合の, これらの $3 \mathrm{wt} \%$ 塩 化ナトリウム水溶液中での電位経時変化である。塗装系 （6）では多少の電位低下はみられるものの, 浸漬 400 日 後も著しい低下はみられなかった。この塗装系の分極抵 抗はすでに検討したよらに，浸漬の過程ではほとんど変 化がなく，また交流抵抗の経時変化も至とえど認められ なかった。下地の種類にかかわらずこのような特性を有 するものが，実用塗膜として望ましいものと考えられ る。本報告では下地の影響をより明確に把握する目的 で, エポキシ樹脂塗料 $\mathrm{A}, \mathrm{B}$ を実験に供した。図 6 の塗 装系 (2) の例では，浸漬 50 日で $-400 \mathrm{mV}$ vs. S.C.E. で あったが，100日を越すと $-650 \mathrm{mV}$ vs. S.C.E.に近づ き, 素地の鉄の電位とほぼ等しくなった。

図 7 に, 図 6 の塗装系(2), (4) と同種のエポキシ樹脂 塗料を上塗りとしたジンクリッチペイント塗装系(1), (3) の場合を示した。塗装系 (1) の電位挙動は, 塗装系 (2) のそれとは全く異なるもので, 浸漬初期の電位を 400 日 経過後も依然保持し続けた。初期 50 日に $-250 \mathrm{mV}$ vs. S.C.E. であったものが浸漬 300 日まで貴方向へ $100 \mathrm{mV}$ 程度移行し, 再び卑方向へ移動した。この現象の理由は 明確に説明できないが，エポキシ樹脂塗膜の硬化，吸水 過程と関係があることも考えられる。整装系 (4) では, 浸漬初期の電位は $-150 \mathrm{mV}$ vs. S.C.E. であったもの が，経時的にほぼ直線的に卑の方向へ移行し，400 日を 経過して $-550 \mathrm{mV}$ vs. S.C.E. 程度にまでなった。

一方ジンクリッチペイント下塗り塗装系 (3) では, そ の電位は $-200 \mathrm{mV}$ vs. S.C.E. と貴な電位を維持し，浸 漬 250 日では次第に卑に移行する傾向が現われたが，塗 装系 (4) に比して未だ著しく貴な電位を与えた。

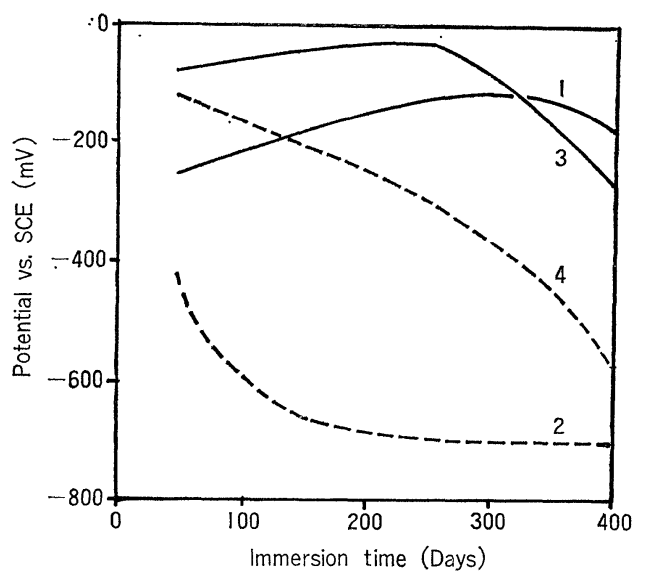

Fig. 7. The potential change with immersion time of epoxy coated steel with and without zinc rich paints (ethylsilicate). 
かくして, サンドブラスト処理鋼板に塗装したエポキ シ樹脂塗膜塗装鋼板の電位は, 著しく卑方向へ移行し, 最終的には無叙装鋼板の電位化近づいた。これに対し， ジンクリッチペイント下染りエポキシ樹脂塗装鋼板の電 位は最終的には若干の低下は認められたものの大きな変 化はなかった。後者はジンクリッチペイント下塗り鋼板 であることから本来電位は, 前者に比較して卑で活るは ずである。しかしながら結果は全く逆になった。これい ジンクリッチペイント下塗り塗膜を有する系では, 上塗 り塗膜との層間での笍食が少ないか，腐食生成物の塗膜 久陷発生への影響が傼かであるために，上塗り塗膜の劣 化が少なく，高抵抗が維持され電位が貴にあると考光ら れる。

これまでに検討した, 分極抵抗の経時変化, 交流抵抗 の経時変化，それに電位の経時变化のいずれをみても， ジンクリッテペイント下塗りエポキシ樹脂塗膜塗装采 (1)，(3)，(5) の变化はいずれもきわめて少ないもので 品た。このことは, ジンクリッチペイント下塗りエ ポキシ樹脂鉒膜が依然として健全で岕ったと推定され る。

食塩水浸漬の溒装鋼板の防食性, 塗膜の劣化過程の検 討を試みる場合，無叙装鋼板の同一環境中での腐食の状 態と大きく異なり，腐食速度が極めて小さいために，塗 膜下の金属の腐食はややむすると見過される傾向にあ る。しかしながら，この腐食速度が僅かとい克ども，塗 膜下金属界面の腐食は確実に進行することは事実であ

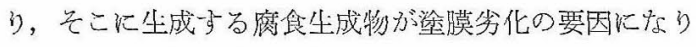
得ることは容易に推定できる。

この点を検討する目的で, 浸漬過程に和ける湿潤淎膜 の付着強度を測定した。浸漬 70 日で, 浸漬液より引き 上げてから20 分後に, 引っ張り試験に供した。浸清開 始前の測定值と比較すると，いずれの場合も付着力は低 下した。特にサンドブラスト処理鋼板に直接エポキシ樹 脂塗装した系の場合に，著しい付着力低下が認められ た。付着破塤部位を棓しく観察すると，浸漬前にはエポ キシ樹脂塗膜内の凝集破墂（図 8 (c) 右）であったもの が，浸漬 70 日後には素地面でのはく離が諗められた (図 8 (c) 左)。これに対しジンクリッナヘイント下塗り ニポキシ樹脂塗膜では，浸漬 70 日で確実に付着低下は 認められたものの，父の破流部位は浸渍前と同様にエポ キシ樹脂塗膜内，悉たはジンクリッチペイント塗膜内で の凝集破壊であり, 鋼板素地面, ジンクリッチペイント とェポキシ樹脂塗膜との界面でのはく離は認められなか った（図 8 (d))。

この付着はく離鋼板面は局部的に $\mathrm{pH}$ が 13 程度であ つた。この結果は, 鋼板界面に生成するアルカリによる 付着性不良が原因とも推定される。これを示唆する実験

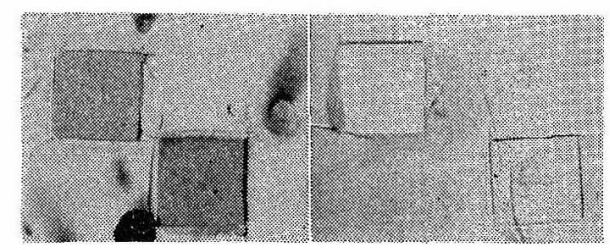

after immersion service before immersion service (c) without zinc rich paint

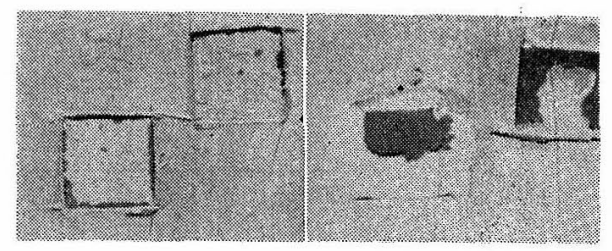

after immersion service before immersion service (d) with zinc rich paint

Fig. 8. Photos of peel-off test after 70 day immersion service.

結果として，サンドブラスト処理鋼板に全く同時に塗装 した試験片を 2 枚用意し，关の一方は暴気食塩水に浸漬 し, 他方は脱気浸漬して, 塗膜欠陥の発生過程它観察し たところ, 前者は浸漬 70 日でフクレが発生し, 後者は 150 日を過ぎてフクレの発生が認められた。溶存酸素の 還元反応によるアルカリ生成が塗膜下で和こるため, 付 着不良が加速されるものと考兄られる。これは塗膜下腐 食が塗膜の付着劣化に影響する顕著な例である。

\section{4. 結 論}

ジンクリッチペイント下塗りエポキシ樹脂塗装系の耐 塩水性に及洔すジンクリッチペイントの效果を艺の評価 方法と共に検討した。叙装鋼板の分極抵抗の経侍変化, 自然電極電位の経時変化，交流抵抗の経時変化のそ艺艺 れの測定から，塗膜欠陷の発生を予測する際に有用から 容易な評洒方法となりらることが判明した。

これらの結果をまとめると，

i）塗膜欠陥が生じにくい塗装系では，高い分極抵抗 が長期間持続した。これはエポキン樹脂塗膜下の亜鉛の 虑食電流が長期間抑制され続けたことを意味する。るた これにより，上叙りで㐫るエポキシ樹脂叙膜が長期間健 全浽維持された。

ii）交流抵抗の経時変化の測定から，ジンクリッチペ イント下叙りエポキシ樹脂塗装系では, その交流抵抗の 低下は嚾かであった。

iii）塗装鋼板電位の経時空化汇掠いて，ジンクリッチ ペイント下塗りエポキシ樹脂塗装系では, 自然電極電位 の卓方向への移行が極めて少なからた。また本来のジン クリッチペイント塗装鋼板，および素地鋼板の自然電極 
電位挙動を考慮すると, 前者にエポキシ樹脂塗装した場 合の方が卑の電位を与えることが考学られるが，本報の 結果は逆であった。これは, この塗装系の浸漬過程での エポキシ樹脂塗膜の劣化が少なく, 塗膜が有効に機能し ているためと考光られる。

電気化学的な評価では, ジンクリッチペイントをその 下塗りとすれば，エポキシ樹脂塗装系の塗膜の耐久性が より優れることが結果として得られた。

(Received January 17, 1981)

$$
\text { 文献 }
$$

1）たとえば Ross T. K. and Lingard J.： Transaction of the Institute of Metal Finishing, 40, 186 (1963).

2) H. H. Chua, B. V. Johnson and T. K. Ross: Corrosion Science, 18, 505 (1978).

3）秋庭徹郎, 松本康彦, 佐藤昭夫：防 食技術， 17, No. 2, 10 (1968).

4) Daniel H. Gelfer and Paul Van Dorsten: Corrosion, 80, Paper Number 113 (1980).

5) 佐藤 靖, 星野 稔, 田辺弘往：防食技術, 28, 524, (1979).

6) 田辺弘往, 篠原稔雄, 佐藤 靖, 新居 博, 星野 稔，伊丹慶輔：防食技術，29, 290 (1980). 